\title{
The Myth and Anti-myth of Venice
}

The word "myth" generally is loaded with pejorative or unverifiable connotations, but this understanding is not always found among historians of Venice for a complex set of reasons. Like most other Italian cities in the Renaissance, Venice had an official historian charged with promoting the memory of the city's past and its good name (Cozzi 1963-4). Gina Fasoli, the historian who fashioned the expression "the myth of Venice," notes that "no other modern state possessed like Venice a sense of the practical value of history in the educational and civic formation of citizens and in the shaping of public opinion abroad" (1958, 450; see also Gaeta 1961, 1981). Modern historians have followed Fasoli in using the expression to draw attention to the historical reputation enjoyed by the Republic of Venice over the centuries. The myth of Venice as a good republic encompasses multiple positive dimensions: Venice's distinctive origins, its place in geography and history, the longevity of its republican government and institutions, its cultural activities, the spiritual and moral association of the republic with St Mark the Evangelist, and the symbols, rituals, and ceremonies that characterized public life and instilled the civic patriotism that reached down to the common people and that described what patricians were expected to wear and how to behave in public and in transacting government business. The myth of Venice thus derives from multiple sources, but its various dimensions sought to create, maintain, and regenerate solidarity and trust among the population, while offering lessons and images of city life that awed visiting foreign observers. Several modern historians of Venice have built on, and extended, observations gleaned from travelogues, local chronicles, and official city histories to show that people create their own realities and often act on those realities. This ritualization of society and the resulting civic patriotism were important elements in accounting for Venice's long-term stability (e.g., Burke 1994; Muir 1981; Robey and Law 
1975; cf. Trexler 1980). The myth thus had a fixed text. But, as Patricia Fortini Brown notes, "its strength lay in its mutability. Within the main lines of the myth, succeeding generations of Venetians could respond to the vicissitudes of political necessity" (1991, 527; cf. on myth Darnton 1990, 3, 329-31).

The myth of Venice is comparable to what social scientists refer to as "folk theory of democracy, a set of accessible appealing ideas assuring people that they live under an ethically defensible form of government that has their interests at heart" (Achen and Bartels 2017). Just as in the case of the myth of Venice, the credibility of the folk theory of democracy has been severely undercut by a growing body of evidence presenting a considerably darker view of democratic politics by examining what actually happens in democratic politics. What researchers have found is that the practice of politics sharply differs from founding "myths" or justifications. Voters are poorly informed, and even those who claim they are well informed often choose parties and candidates on the basis of social identities and partisan loyalties. Voters tend not to choose on the basis of policies, there is little or no internal party democracy (as Gaetano Mosca [1896] 1939 noted of parliamentary government more than a century ago), elections do not produce responsive government, and bureaucratic administration is not accountable. Even when growing economic inequalities are acknowledged, taxing the rich remains a challenge. There is a huge gap between the practice and the doctrine ("the foundational myth"?) of democratic governance. The list of reported dissatisfactions with democratic politics is long and for the most part convincing. This state of affairs has led some analysts, particularly in the American case, to build up a case against democracy in favour of epistocracy, the rule of the knowledgeable (e.g., Brennan 2017).

Just as comparativists have been revising the accepted view of democracy, so have historians of Venice. Several decades of modern historiography have made clear that the myth of Venice as a good republic has lost the power it once had, and that that very myth helped to generate a counter- or anti-myth of Venice (Grubb 1986; see also Martin and Romano 2000, 2; Romano 2007, 339-43). The origins of the counter- or anti-myth of Venice can be traced back as far as the fifteenth century, when Venice was expanding its hold over the mainland, the terraferma. Venice was now being portrayed as governed by a secretive oligarchy, utterly controlled by a group of wealthy families who established a police state using torture and a network of informers to maintain power, plagued from time to time with eruptions of the social tension that existed between the highly stratified classes, and regarded by most of its neighbours as a dangerous and arrogant bully, with much of its wealth guaranteed by vigorously enforced 
monopolies over trade and, of course, by simple plunder. Not surprising, the anti-myth became prominent in France, where Venetian ideas of government countered the dominant absolutist tendencies of late sixteenth- and seventeenth-century political thought and practices (Muir 1981, 50). Jean Bodin gave theoretical coherence to the anti-myth in his work on sovereignty (see, e.g., Gianturco 1938; Gordon 1999, 21-4). By the eighteenth century, the republicanism of Venice appeared to people like Rousseau, who had spent time there as secretary to the French ambassador, a "simulacrum" or an anachronism in an age characterized by large unitary states. The democratic aspirations generated by the French Revolution and Napoleon Bonaparte's threat to take the city by force in 1797 "snuffed out" the Republic (Romano 2007, 343). ${ }^{14}$ By the end of the twentieth century the anti-myth of Venice had gained considerable credibility and power among historians (Grubb 1986; Martin and Romano $2000,3)$. Not surprisingly, in modern scholarship Venice "is no longer represented as the Exemplary Republic" (Martin and Romano 2000, 8).

Yet, just like the folk theory of modern democracy, the reality of Venice as a good republic is built on more than a myth or a grain of truth. Its undeniable social and economic inequalities were commonplace in the pre-modern world. When matters are put in comparative historical perspective, the Venetian inequalities and oligarchic tendencies did not appear as such to many Renaissance writers (Fink 1945, 32-3; see also Fink 1940; Gilmore 1973). Even Bodin, no admirer of Venice, admitted that the city attracted "those who aspired to live in the greatest freedom and tranquility; people who wished to engage in trade or industry, or to pursue studies worthy of free men" (quoted in Gordon 1999, 135). While other communes degenerated into unstable signorie (e.g., Jones 1997), "Venice avoided the dominance of any single family and perfected a system of checks and balances within its ruling class" (Lane 1966a, 412). For most of its history, Venice avoided the internecine warfare, political assassinations, and religious chaos that bedevilled most of its neighbours in Italy and the Balkans. The aspects of Venice that most intrigued foreign observers were, in fact, its relatively high degree of social and political tranquility and its economic wealth and cultural creativity. Often against overwhelming odds, Venice retained, across time and space, its independence, political resilience, and constitutional robustness to be the admiration or envy of many thinkers, included the Florentines Machiavelli and Guicciardini (see also Muir 1981, 45-50). One political

14 Perhaps the best expression of the anti-myth of Venice in the second half of the nineteenth century may be found in chapter 22 of Mark Twain's Innocents Abroad (Gordon 1999, 134n3). 
economist summed things up this way: "What historians have come to call 'the myth of Venice' refers to the conception of Venice as an ideal republic that in itself influenced Western political theory and constitutional development" (Gordon 1999, 156). For as historian Robert Darnton $(1990,3)$ notes in another context, "myths can move mountains. They can acquire a rocklike reality as solid as the Eiffel Tower, which the French built to celebrate the one hundredth anniversary of the Revolution in 1889." It is truly hard for any society, organized political community, or "perpetually lived organizations" (North, Wallis, and Weingast 2013) to exist without myth, good and bad. 